\title{
AL-AWQAF
}

Jurnal Wakaf dan Ekonomi Islam

Vol. 14, No. 1, Tahun 2021

\section{Pengelolaan Wakaf Produktif di Lembaga Amil Zakat Nurul Fikri Sampit Ditinjau dari Undang-Undang Nomor 41 Tahun 2004 Tentang Wakaf}

\author{
Sudirman ${ }^{1}$ Erna Sari ${ }^{2}$ \\ ${ }^{1}$ Universitas Islam Negeri Maulana Malik Ibrahim Malang, sudirman@syariah.uin-malang.ac.id \\ ${ }^{2}$ Universitas Islam Negeri Maulana Malik Ibrahim Malang, ernasari2210@gmail.com
}

\begin{abstract}
Lembaga Amil Zakat Nurul Fikri as the object of research for various reasons underlying this paper, including the policy of zakat institutions to receive waqf. Basically, the authority of zakat institutions is only to receive zakat infaq and shadaqah, but it is different from Nurul Fikri who also receives and manages waqf. Among them productive waqf that is being managed is productive sengon tree whose initial allocation of waqf is to build educational institutions. In this article, it contains about how the legality of waqf institution law has authority as nadzir waqf and how to manage and develop productive waqf if reviewed from Law No. 41 of 2004. This type of research is empirical or field research that uses description analysis with qualitative approach. The results showed that 1) Zakat Nurul Fikri Institution receives authority as nadzir waqf because of the encouragement of social factors of the community to make some of its assets, in addition this Institution also makes a program of the establishment of an independent waqf institution and the plan is a program that will be established in 2021 . 2). In developing and managing productive waqf Nurul Fikri has followed in accordance with what is intended by law No. 41 of 2004, but there are several things that need to be improved related to institutional problems.
\end{abstract}

Keywords: productive waqf, management, nadzir

Abstrak: Lembaga Amil Zakat Nurul Fikri sebagai objek penelitian karena berbagai alasan yang mendasari tulisan ini, diantaranya adalah karena kebijakan Lembaga Zakat untuk menerima wakaf. Pada dasarnya, kewenangan lembaga zakat hanya untuk menerima zakat infaq dan shadaqah, namun berbeda halnya dengan Nurul Fikri yang juga menerima serta mengelola wakaf. Diantaranya wakaf produktif yang sedang dikelola adalah produktif pohon sengon yang peruntukan awal wakaf tersebut adalah untuk membangun lembaga pendidikan. Dalam hal tersebut pada tulisan ini berisi tentang bagaimana legalitas hokum lembaga wakaf memiliki wewenang sebagai nadzir wakaf serta bagaimana pengelolaan dan pengembangan wakaf produktif jika ditinjau dari UU No. 41 Tahun 2004. Jenis penelitian ini adalah jeneis penelitian empiris atau lapangan yang menggunakan analisis deskripsi dengan pendekatan kualitatif. Hasil penelitian menunjukkan bahwa 1) Lembaga Zakat Nurul Fikri menerima kewenangan sebagai nadzir wakaf karena dorongan faktor sosial masyarakat untuk mewakafkan sebagian hartanya, selain itu Lembaga ini juga membuat program pembentukan Lembaga wakaf yang independen dan rencana tersebut merupakan program yang disegerakan akan dibentuk pada tahun 2021. 2). Dalam mengembangankan dan mengelola wakaf produktif Nurul Fikri telah mengikuti sesuai dengan apa yang diperuntukkan oleh 
undang-undang No. 41 Tahun 2004, namun ada bebrapa hal yang perlu diperbaiki terkait masalah kelembagaan.

Kata Kunci: wakaf produktif, pengelolaan, nazhir

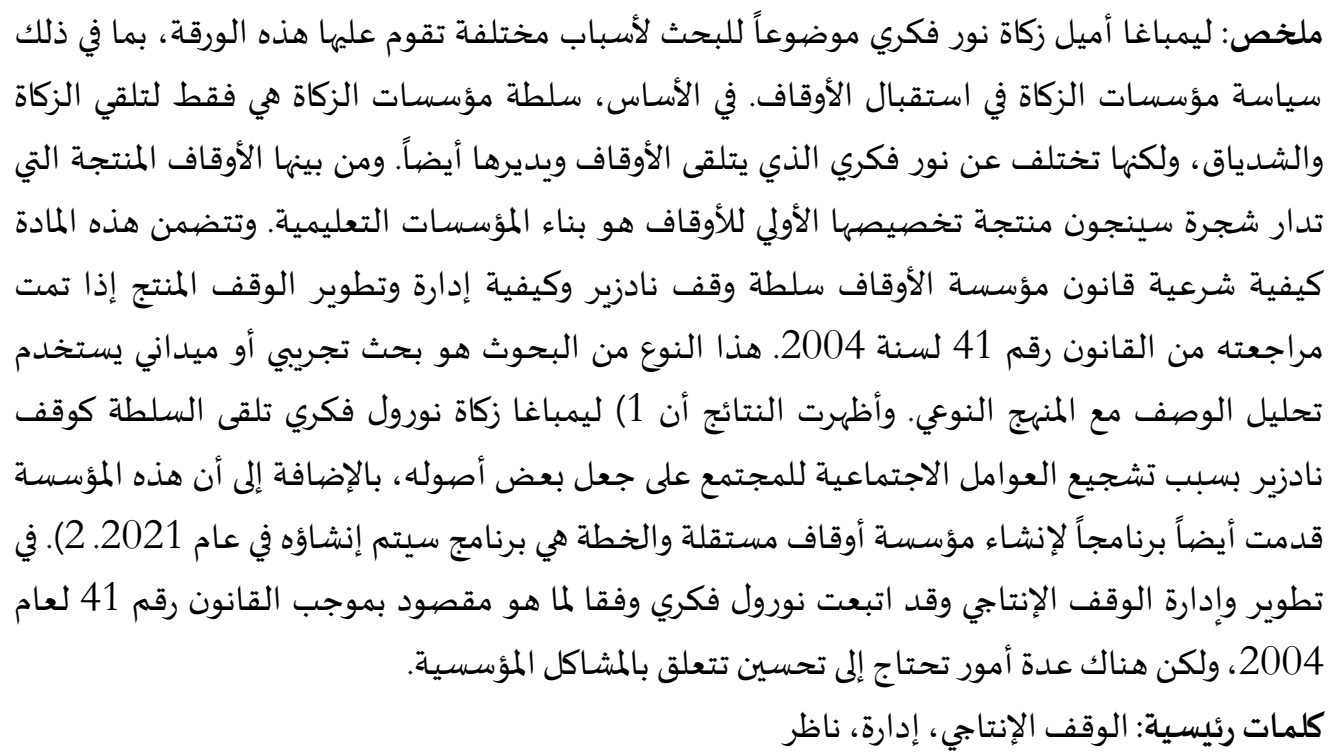

\section{Pendahuluan}

Pada pengelolaan wakaf, hal yang pertama harus ada adalah badan wakaf yang memiliki wewenang menjaga, mengelola, serta mengembangkan asset wakaf tersebut. Dalam pembahasan di Indonesia, lembaga wakaf yang berdiri secara independen akan mengelola dana wakaf dan beroperasi secara nasional biasa dikenal dengan sebutan Badan Wakaf Indonesia (Djunaidi, 2017). Sebagaimana yang tertuang pada UU No. 41 tahun 2004 pasal 49, salah satu tugas penting dari BWI yaitu melakukan pembinaan terhadap nadzir wakaf dan melakukan pengawasan terhadap pengelolaan harta benda wakaf. Sebgai penguat dari UU tersebut, pada Peraturan BWI No.1 Tahun 2007 Tentang Organisasi dan Tata Kerja Bada Wakaf Indonesia diantaranya yaitu: a) BWI akan melakukan pembinaan kepada nadzir pada pengolahan dan pengembangan harta benda wakaf, b) BWI akan membuat sebuah pedoman yang akan digunakan sebagai acuan pengelolaan dan pengembangan harta benda wakaf, c) BWI akan melakukan pengolahan harta wakaf yang berstandar Nasional bahkan Internasional.

Dalam regulasi di Indonesia jelas disebutkan bahwa keberadaan Lembaga wakaf Khususnya BWI sangatlah penting karena eksitensi BWI yang strategis untuk membantu baik terhadap hal pembiayaan, pembinaan maupun pada pengawasan pada pengelolaan wakaf yang dilakukan secara produktif. Hal ini menjadi salah satu kendala bagi peneglolaan wakaf yang ada di Sampit. Berbanding dengan keinginan masyarakat yang ingin mewakafkan sebagian harta mereka, maka Lembaga Zakat Nurul Fikri yang kewenangannya dalam bidang zakaf, infaq dan shadaqah harus menerima dan mengelola harta benda wakaf.

Dalam situasi dimana belum dibentuk badan wakaf yang independen, dikhawatirkan pengelolaan wakaf tersebut tidak berjalan secara optimal. Karena pembinaan dan pengawasan terhadap kinerja nadzir tidak ada yang memperhtaikan. Sedangkan ditangan nadzir lah titik 
keberhasilan dan kegagalan dari pengelolaan wakaf. Meskipun demikian, berkaitan dengan urgensi lembaga wakaf untuk pengelolaan wakaf, di Kota Sampit belum terbentuk lembaga wakaf sebagaimana yang telah disebutkan. Dengan demikian peneliti melakukan penelitian di Lembaga Amil Zakat Nurul Fikri yang notabenenya menglola zakat namun lembaga ini juga menerima wakaf serta meneglolanya. Lembaga ini dapat dikatakan melakukan diskresi kewenangan.

Adapun tindakan penggunaan diskresi hukum ini berujuan untuk mengisi kekososngan hukum, memberikan kepastian hukum dan mengatasi stagnasi pemerintah dalam keadaan tertentu guna kemanfataan dan kepentingan umum sebagaimana tertuang dalam undangundang Nomor 30 tahun 2014 pasal 22 poin kedua. Tidak ada pihak yang menerima wakaf dari wakif baik berupa perorangan, organisasi, maupun badan hukum. Oleh karena itu, Lembaga Amil Zakat Nurul Fikri memebrikan kontribusi secara maksimal demi melayani kepentingan masyarakat dengan menerima wakaf yang disalurkan meskipun bukan kewenangannya untuk meneglola harta benda wakaf.

Selain itu, factor sosiologis merupakan factor utama penerimaan wakaf pada lembaga ini. Masyarakat juga memiliki kepercayaan untuk menitipkan dananya pada lembaga ini. Nurul Fikri bukan satu-satunya Lembaga Zakat yang menerima wewenang sebagai Nadzir. Hal serupa juga terjadi pada LAZ Al-Hilal di Bandung. LAZ ini melakukan presentasi rencana program wakaf uang untuk pengembangan lembaga. Al-Hilal telah menerima wakaf dalam bentuk uang yang kemudian dijadikan asset berupa lahan tanah, bangunan gedung asrama, dan saat ini sedang melakukan proyek pembangunan masjid yang dibangun khusus untuk anak yatim dan santri tahfidz.

\section{Metodologi}

Jenis penelitian pada penelitian ini yaitu penelitian empiris atau sosiologis yang merupakan penelitian dilakukan terjun langsung ke lapangan (Prastowo: 2011). Lebih rincinya jenis penelitian yang dimaksud adalah mengungkapkan segalaimplementasi hukum yang berada dalam masyarakat umum dilihat dari perbuatan ataupun tingkah laku masyarakat itu sendiri. Pendekatan penelitian yang digunakan pada riset ini merupakan pendekatan penelitian kualitatf yang bebararti penelitian yang bertujuan untuk menekankan terhadap aspek pemahaman yang lebih mendalam terhadap suatu masalah. Sumber data yang digunakan pada penelitian ada dua yaitu sumber data primer dan sumber data sekunder. Sumber data yang primer yang digunakan pada riset ini mengambil data langsung pada penelitian dengan menggali informasi langsung kepada nadzir wakaf produktif di LAZ Nurul Fikri untuk mengetahui bagaimana pengelolaan wakaf produktif dilembaga tersebut. Sumber data sekunder pada penelitian ini diambil dari Al-Qur'an dan Hadis, buku-buku yang menyinggung tentang wakaf produktif, dan Undang-undang yang menyinggung tentang wakaf seperti Undang-undang Nomor 41 Tahun 2004.Peneliti menggunakan berbagai macam metode pengumpulan data yang sesuai apa yang diperlukan peneliti, agar mencapai hasil yang objektif. Adapun metode pengumpulan data yang digunakan yaitu; 1) Wawancara kepada Wirahadi, Lc, Zulkifli, S.EI, M. Sy, Putri Rahayu Ningsih, dan Siti Aisyah, S.M. 2) Dokumentasi. 


\section{Wakaf Produktif}

Segala wakaf harta yang digunakan untuk kepentingan produksi baik dalam bidang pertanian, perindustrian, perdagnagn dan jasa yang manfaatnya bukan berasal dari benda secara langsung, melainkan berasal dari laba atau keuntungan bersih hasil pengembangan wakaf yang diberikan kepada orang-orang yang berhak menerima wakaf merupakan penegrtian dari wakaf produktif. Wakaf produktif ini dikelola dan dikembangkan yang kemudia dijual dan hasil dari penjualan tersebut dipergunakan sesuai dengan tujuan wakaf tersebut.

Wakaf adalah harta ataupun barang yang diserahkan kepada penerima wakaf baik perorangan, organisasi ataupun badan hukum yang seketika harta tersebut diserahkan maka seketika itu pula harta tersebut menjadi milik public sebagaimana telah disebutkan dalam pasal 1 undangundang 41 Tahun 2004. Lembaga wakaf yang merupakan nadzir dalam peruntukkan dan pengembangan wakaf memiliki fungsi dan tujuan untuk pemanfaatan, pemberdayaan, dan penggunaan harta wakaf. Selain itu lembaga wakaf juga memiliki fungsi untuk melindungi tujuan wakaf sebagaimana yang telah diikrarkan oleh wakif.

Wakaf produktif merupakan ide atau gagasan mengenai pengelolaan donasi harta wakaf yang diterima dari umat, yaitu dengan cara memproduktifkan donasi tersebut, sehingga akan menghasilkan keuntungan atau surplus yang secara terus menerus. Wakaf tersebut diolah agar dapat menghasilkan barang ataupun jasa yang kemudian barang atau jasa tersebut diperjualbelikan. Hasil dari penjualan tesebut dialihkan kepada peruntukan tujuan awal wakaf.

Terjadi selisih pendapat antar ulama yang satu dengan ulama yang lain. Adapun pengertian wakaf menurut ahli fikih yaitu : a) Wakaf menurut Abu Hanifah yaitu menahan suatu benda yang dalam kacamata hukum tetap milik si pewakaf dalam hal mempergunakan manfaatnya untuk kebijakan. Berdasarkan definisi tersebut maka peilik harta wakaf tidak lepas dari wakif, bahkan wakif diperbolehkan untuk menarik kembali harta wakaf tersebut dan wakif juga diperbolehkan untuk menjualnya. b) Wakaf menurut Imam Maliki. Beliau berpendapat bahwa wakaf itu tidak melepaskan harta yang diwakafkan dari kepemilikan si pewakaf, namun wakaf tersebut mencegah tindakan wakif untuk melakukan hal yang dapat melepaskan kepemilikannya atas harta tersebut kepada yang lain dan wakif berkewajiban menyedekahkan manfaatnya serta tidak boleh menarik kembali harta yang telah diwakafkan (Bakhri: 2017), c) Wakaf menurut Imam Syafi'I dan Imam Ahmad bin Hanbal. Menurut pendapat beliau wakaf adalah melepaskan harta yang diwakafkan dari kepemilikan wakif setelah melakukan segala prosedur wakaf dengan sempurna. Wakif tidak boleh melakukan apapun terhadap harta yang diwakafkan (Khusaeri: 2015)

\section{Dasar Hukum Wakaf}

Dalam al-Qur'an tidak disebut secara eksplisit mengenai dasar hukum wakaf. Akan tetapi, para ulama fikih merujuk kepada ayat yang beririsi tentang perintah untuk mendonasikan sebagian rezeki yang diterimanya seperti halnya ayat yang menyinggung tentang kebaikan dan keutamaan shadqah, infak dan amal jariyah. Para ulama sependapat untuk menafsirkan bahwa bahasan permasalahan wakaf mencakup dalam ayat tersbut. Adapun ayat yang dimaksud yaitu "Kalian sekali-kali tidak sampai kepada kebajikan (yang sempurna) sebelum kalian 
menafkahkan sebagian harta yang kalian cintai. Dan apa saja yang kalian nafkahkan, maka sesungguhnya Allah mengtahuinya”.

Dalam ayat tersebut dijelaskan bahwa apabila ingin sampai pada suatu kebaikan yang sempurna dapat dilakukan dengan cara mmembagikan harta yang dimilikinya. Membagikan harta yang dimaksud bukanlah secara keseluruhan, melainkan sebagian dari harta yang dimilikinya dan tentu harta tersebut merupakan harta yang dicintainya.

Dengan menyisihkan dengan wakaf sebagian harta yang dicitainya maka akan tampak keseriusan dan kesungguhan untuk berwakaf. Sebagaimana contohnya yaitu mewakafkan tanah yang berada didaerah perkotaan, diperkirakan tanah tersebut semakin tahun akan mengalami kenaikan harga. Akan tetapi karena untuk mengharapkan ridha Allah, seseorang tidak akan merasa rugi dan menyesal melainkan merasan mendapatkan keuntungan karena dapat memberikan kemanfaatan untuk kepentingan dan kemaslahatan umat. Dengan demikian terdapat kepedulian sosial dalam diri wakif. Sebagaimana dalam firman Allah yang artinya "Perumpamaan (nafkah yang dikeluarkan oleh) orang-orang yang menafkahkan hartanya di jalan Allah adalah serupa dengan sebutir benih yang menumbuhkan tujuh bulir, pada tiap-tiap bulir seratus biji. Allah melipatgandakan (ganjaran) bagi siapa yang Dia kehendaki. Dan Allah Mahaluas (karunia-Nya) lagi Maha Mengetahui”.

Ayat diatas menjelaskan bahwa berwakaf yang dimaksud adalah berwakaf yang seharusnya bertujuan untuk mendapatkan ridho Allah SWT. Dengan demikian, dapat dianalogikan bahwa orang yang berwakaf itu serupa dengan memberikan sebutir benih, yang mana benih tersebut akan menumbuhkan tujuh butir dan setiap butirna terdapat seratus biji.

\section{Rukun dan Syarat Wakaf}

Dalam Islam, segala sesuatu yang dilakukan akan bernilai sah apabila telah terpenuhi segala rukun beserta syaratnya. Begitu pula dalam hal perwakafan terdapat syarat dan rukun yang harus dipenuhi.

Secara etimologi, rukun diartikan sebagai sisi yang terkuat. Sedangkan dalam terminologi, rukun yaitu segala sesuatu yang dianggap umtuk menentukan suatu disiplin tertentu. Para ulama berselisih pendapat dalam menentukan rukun wakaf. Perselisihan tersebut merupakan implikasi dari perbedaan mereka dalam memandang substansi harta benda wakaf. Para ulama Hanafiyah berpendapat bahwa rukun wakaf hanyalah sebatas shighat yang menunjukkan makna ataupun substansi itu sendiri. Sedangkan menurut pendapat ulama Malikiyah, Syafiiyah, Zaidiyah dan Hanabillah mengatakan bahwa rukun wakaf itu meliputi wakif, manquf alaih, harta yang diwakafkan dan shighat. Adapun rukun wakaf menurut fiqh mayoritas yaitu: orang yang mewakafkan atau biasa disebut dengan istilah wakif, barang yang diwakafkan atau biasa disebut dengan istilah manquf bih, peruntukan wakaf atau biasa disebut dengan istilah manquf 'alaih, dan ikrar wakif atau biasa disebut dengan istilah shighat (Ishari, dkk: 2016).

\section{Jenis Wakaf}

Menurut Fyzee yang mengutip dari pendapat Ameer Ali membagi wkaaf enjadi tiga bagian, yaitu: a) Untuk kepentingan yang kaya dan yang miskin dengan tidak berbeda, b) Untuk 
kepentingan yang kaya dan sesudah itu baru untuk yang miskin, c) Untuk keperluan yang miskin semata-mata (Sari: 2007)

Jika ditinjau dari segi peruntukannya, wakaf terbagi menjadi dua yaitu: a) Wakaf Ahli. Wakaf ahli adalah wakaf yang hanya ditujukan kepada orrang-orang tertentu, baik itu kepada keluarga si pewakaf ataupun bukan. Wakaf jenis ini biasa dikenal dengan istilah wkafa dzurri. b) Wakaf Khairi. Wakaf khairi adalah wakaf yang secara khusus diperuntukkan untuk kepentingan umum seperti keagamaan ataupun kemasyarakatan. Sebagai contoh harta wakaf yang diperuntukkan untuk pembangunan mesjid, pendirian sekolah, pembuatan jembatan, pembangunan rumah sakit, pembangunan panti asuhan dan yang lain sebagainya (Kamelia: 2018).

\section{Nazhir}

Menurut etimologi kata nadzir memiliki arti menjaga atau mengurus. Didalam kasus Bahasa Arab, disebutkan bahwa nadzir memiliki arti kata yang melihat, pemeriksa (Yunus: 1973). Dalam artian terminology, kata nadzir memiliki arti pihak tertentu yang melakukan pemeriksaan. Selain itu nadzir juga dapat diartikan sebagai pihak yang memiliki tugas untuk melakukan pemeriksaan suatu objek ataupun sesuatu hal yang berkaitan dengan objek yang akan terdapat dalam pemeriksaannya itu. Dalam literature lain disebutkan bahwa nadzir merupakan seseorang yang memiliki peran penting sekaligus orang yang memiliki tanggung jawab yang tinggi terhadap harta wakaf yang telah dipercayakan kepadanya, baik hal tersebut dari segi pemeliharaannya, upaya pengembangangannya maupun terhadap hasil dari harta wakaf tersebut.

Keberadaan nadzir sangatlah diperlukan, bahkan menempati peran yang utama. Hal ini dikarenakan dipundak nadzirlah kewajiban dan tanggung jawab pemeliharaan, penjagaan serta pengembangan wakaf dan penyaluran hasil atau manfaat dari harta benda wakaf kepada sasaranya. Maka didalam kekuasaan nadzir pula pemanfaatan aset wakaf bersifat konsumtif ataupun dikelola secara produktif. Selain itu keberhasilan wakaf produktif dapat dilihat dari cara ataupun metode yang digunakan dalam mengelola serta mengembangkan wakaf tersebut.

Berbicara mengenai arti penting yang dimiliki oleh peranan seorang nadzir dalam mengelola harta wakaf tersebut, para imam madzhab sependapat tentang urgensi nadzir untuk memenuhi syarat adil dan mampu. Adil yang dimaksud disini adalah mengerjakan segala apa yang diperintahkan dan menjauhi semua hal-hal yang telah dilarang. Sedangkan mampu disini memiliki kekuatan dan kemampuan untuk mentasarufkan apa yang dijaganya dana apa yang menjadi tanggung jawabnya. Dua syarat tersebut merupakan kunci dari nadzir untuk mencapai keberhasilan dari pengelolaan wakaf produktif.

Profesionalitas dan kualitas seorang nadzir dalam meneglola harta wakaf tidak mungkin dapat terwujud jika dalam hal kesejahteraannya tidak terpenuh bahkan diabaikan. Mereka berhak mendapatkan gaji sesuai dngan hasil kinerjanya yang diambil dari hasil harta wakaf tersebut dan sesuai dengan standar penggajian secara umum.

Indonesia merupakan negara hokum yang mana setiap tindakan yang akan dilakukan harus sesuaai dengan aturan yang telah dibuat oleh pemerintah. Begitupun dengan aturan yang 
membahas mengenai wakaf produktif. Dalam regulasi Indonesia disebutkan dalam Undangundang No. 41 Tahun 2004 pasal 12 dijelaskan bahwa seorang nadzir berhak menerima fee dari hasil bersih atas pengelolaan dan pengembangan wakaf yang dikelolanya, yang mana kisaran jumlahnya tidak melebihi dari 10\%. Gaji nadzir yang diatur dalam undang-undang tersebut lebih banyak dari gaji nadzir dibeberapa negara muslim didunia, seperti Bangladesh, Mesir, Sudan, dan sebagainya (Tiswarni: 2014).

Selain itu, untuk kemajuan serta perkembangan perwakafan Nasional dibentuklah suatu lembaga yang berfungsi sebagai penyelenggara administrasi dalam pengelolaan harta wakaf secara Nasional khususnya yang berkaitan dengan tanah wakaf produktif. Adapun Lembaga tersebut dikenal dengan Badan Wakaf indonesia. Berdasarkan Undang-undang No. 41 Tahun 2004 yang tertuang pada pasal 49 BWI memiliki tugas tersendiri yaitu: 1) BWI melakukan pembinaan kepada nadzir dalam hal mengelola serta mengembangkan harta benda wakaf, 2) BWI melakukan pengelolaan dan pengembangan harta benda wakaf yang berskala nasional dan internasional, 3) BWI berhak memberikan persetujuan dan/aatu ijin perihal perubahan peruntukan dan status harta benda wakaf, 4) BWI memiliki kewenangan untuk memberhentikan nadzir, 5) BWI berhak untuk memberikan persetujuan atas penukaran harta benda wakaf, 6) BWI memberikan saran dan pertimbangan kepada pemerintah dalam penyusunan kebijakan dibidang perwakafan (Sari: 2007)

Dalam masa pandemi seperti ini, permasalah ekonomi yang menurun secara drastis, wakaf produktif dapat menjadi salah satu solusi untuk membantu permasalahn umat, khususnya pada bidang social dan ekonomi. Hal ini dapat terealisasikan apabila seorang nadzir dapat menjalankan tugasnya secara maksimal. Namun, pada kenyataannya, wakaf hanya dijalankan dengan standar miniml sehingga hasil yang diperoleh pun belum maksimal bahkan hanya cukup untuk pengembalian modal penggarapananya saja.

Seorang nadzir yang professional akan mempunyai komitmen dalam pekerjaan yang sedang dilakukannya. Komitmen pribadi yang dimiliki ini lah akan memunculkan sikap tanggung jawab yang besar atas pekerjaannya tersebut. Dalam literature lain disebutkan bahwa nadzir yang professional merupakan seseorang yang melakukan pekerjaannya dengan mengandalkan segala keterampilan dan keahlian yang dimilikinya. Karena keahlian dan keterampilan yang dimilikinya, maka nadzir tersebut akan mengerahkan waktu tenaga dan pikirannya untuk pekerjaan yang sedang dilakukannya (Samsudin: 2011).

Berkaitan dengan tugas-tugas seorang nadzir, Syalabi menegmukakan pendapatnya bahwa kewajiban utama seorang nadzir yaitu mengelola serta memelihara harta benda wakaf. Sebab, apabila dalam pengelolaanya diabaikan maka akan menimbulkan kerusakan dan kehilangan fungsi wakaf tersebut. Oleh karena itu, para fuqaha sependapat bahwa tugas utamanya adalah untuk memelihara harta wakaf.

Dijelaskan kembali mengenai pengelolaan dan pengembangan harta benda wakaf yang tertuang pada undang-undang No. 41 Tahun 2004 tepatnya pada pasal 43 disebutkan bahwa pengembangan dan pengelolaan wakaf yang dilakukan oleh nadzir harus seuai dengan prinsip syariah dan yang dilakukan secara produktif anara lain dengan cara pengumpulan, investasi, 
penanaman modal, produksi, agrobosnis, kemitraan perdagangan, pertambangan, pembangunan rumah sakit, pembangunan pasar swalayan, pertokoan, perkantoran, lembaga pendidikan, sarana kesehatan, dan segala usaha-usaha yang tidak bertentangan dengan syariah. Dalam mengelola dan mengembangakan harta benda wakaf kecuali atas dasar ijin tertulis (Sari: 2007).

\section{Alasan Lembaga Zakat Nurul Fikri Mengelola Wakaf Produktif}

Untuk mengelola wakaf produktif di Indonesia, pertama-tama yang harus ada adalah pembentukan suatu badan atau lembaga independen untuk mengelola wakaf produktif yang ada dan bersifat Nasional atau biasa di Indonesia disebut dengan Badan Wakaf Indonesia (BWI). Namun pada realita yang ada di kota Sampit, Lembaga Zakat memiliki kewenangan menjadi Nadzir untuk mengelola wakaf produktif.

Berkaitan dengan urgensi lembaga wakaf untuk pengelolaan wakaf, di Kota Sampit belum terbentuk lembaga wakaf sebagaimana yang telah disebutkan. Dengan demikian peneliti melakukan penelitian di Lembaga Amil Zakat Nurul Fikri yang notabenenya menglola zakat namun lembaga ini juga menerima wakaf serta meneglolanya. Lembaga ini dapat dikatakan melakukan diskresi kewenangan.

Adapun yang dimaksud dengan diskresi kewenangan sebagaimana disebutkan dalam kamus besar bahasa Indonesia yaitu kebebasan mengambil keputusan sendiri disetiap situasi. Thomas J. Aaron memebrikan definisi diskresi merupakan suatu kekuasaan atu kewenangan yang dilakukan berdasarkan hukum atas pertimbangan dan keyakinan serta lebih menekankan pertimbangan-pertimbangan moral daripada pertimbangan hukum. Pendapat lain dikemumakan oleh Mahfud MD beliau menyebutkan diskresi adalah kewenanangan yang sah untuk turut campur dalam kegiatan soial guna melaksanakan tugas-tugas meneyelnggarakan kepentingan umum (Ramadhita: 2013). Adapun tindakan penggunaan diskresi hukum ini berujuan untuk mengisi kekososngan hukum, memberikan kepastian hukum dan mengatasi stagnasi pemerintah dalam keadaan tertentu guna kemanfataan dan kepentingan umum sebagaimana tertuang dalam undang-undang Nomor 30 tahun 2014 pasal 22 poin kedua. Tidak ada pihak yang menerima wakaf dari wakif baik berupa perorangan, organisasi, maupun badan hukum. Oleh karena itu, Lembaga Amil Zakat Nurul Fikri memebrikan kontribusi secara maksimal demi melayani kepentingan masyarakat dengan menerima wakaf yang disalurkan meskipun bukan kewenangannya untuk meneglola harta benda wakaf.

Selain itu, factor sosiologis merupakan factor utama penerimaan wakaf pada lembaga ini. Masyarakat juga memiliki kepercayaan untuk menitipkan dananya pada lembaga ini. Nurul Fikri bukan satu-satunya Lembaga Zakat yang menerima wewenang sebagai Nadzir. Hal serupa juga terjadi pada LAZ Al-Hilal di Bandung. LAZ ini melakukan presentasi rencana program wakaf uang untuk pengembangan lembaga. Al-Hilal telah menerima wakaf dalam bentuk uang yang kemudian dijadikan asset berupa lahan tanah, bangunan gedung asrama, dan saat ini sedang melakukan proyek pembangunan masjid yang dibangun khusus untuk anak yatim dan santri tahfidz. Selain itu al-Hilal juga menerima wakaf dalam bentuk fisik seperti Al-Qur'an ataupun dalam bentuk uang yang kemudian dibelikan Al-Qur'an. AlQur'an tersebut didistribusikan kepada masyarakat yang mengalami bencana alam, masjid- 
masjid dan juga Madrasah, TPA atau santri tahfidz yang memerlukan terutama dipendalaman atau pelosok Indonesia (Nasfisah: 2019). Berikut adalah data-data dari orang yang ingin mewakafkan sebagian dari harta mereka yaitu:

Tabel 1 Data Orang Yang Wakaf Uang

\begin{tabular}{|l|l|l|l|l|}
\hline No & $\begin{array}{c}\text { Kode } \\
\text { Transaksi }\end{array}$ & \multicolumn{1}{|c|}{ Id } & \multicolumn{1}{|c|}{ Nama Muzakki } & \multicolumn{1}{|c|}{ Alamat } \\
\hline 1 & SPA-1518 & DN0002328 & Rina Pratiwi/ Jito & PT. NSP Desa Kandan \\
\hline 2 & SPA-1515 & DN0000281 & Hamba Allah & \\
\hline 3 & SPA-1513 & DN0000281 & Hamba Allah & \\
\hline 4 & SPA-1510 & DN0002666 & Muhammad Tajri & Jl. Ir.H. Juanda No. 19 \\
\hline 5 & SPA-1505 & DN0000191 & Ramadiyani,S.Pd & $\begin{array}{l}\text { Jl. Sirathal Mustaqim Barat } \\
\text { No. 19 }\end{array}$ \\
\hline 6 & SPA-1495 & DN0002660 & Alpian & Jl. Gatot Subroto No. 30 \\
\hline 7 & SPA-1490 & DN0002577 & Agus Ardyanto & Jl.Muhran Ali No.01 \\
\hline 8 & SPA-1486 & DN0000281 & Hamba Allah & \\
\hline 10 & SPA-195 & DN0000258 & Fitri Saltinah, S.Pd & Jl. Sukabumi No.20 \\
\hline 11 & SPA-188 & DN0000250 & Erny Thoyibatun & Jl. G.Arjuno 5 No.161 \\
\hline 12 & SPA-180 & DN0000191 & Ramadiyani,S.Pd & \\
\hline 13 & SPA-179 & DN0000170 & Kamariah & $\begin{array}{l}\text { Jl. Metro muara 1 no.23 } \\
\text { Sampit }\end{array}$ \\
\hline
\end{tabular}

Tabel 2 Data Yang Mewakafkan Tanah

\begin{tabular}{|l|l|l|}
\hline No & Nama & Alamat Wakaf tanah \\
\hline 1. & Enny Ekowati & Lingkar utara Islamic center \\
\hline 2. & Umi Alfiyah & Bapanggang raya jalur 8 Kebun Karet \\
\hline 3. & Idam Rismawan & Jl. H.M Arsyad Km. 5 \\
\hline 4. & Julian & Jl. Muchran Ali Gg. Padat Karya \\
\hline
\end{tabular}

\section{Pengelolaan Wakaf Produktif Di Nurul Fikri Ditinjau Dari Undang-undang Nomor 41 Tahun 2004 Tentang Wakaf}

Indonesia merupakan Negara dengan kepemilikan sumber daya alam yang sangat kaya dan sebagian besar masyarakatnya penganut agama Islam, namun Negara ini termasuk Negara yang memiliki struktur ekonomi yang masih timpang. Banyaknya kemiskinan dan ketimpangan sosial yang terjadi di Indonesia. Hal ini terjadi karena perekonomian yang strtegis dimonopoli atau dikendalikan oleh sebagian orang yang memiliki penerapan prinsip ekonomi ribawi. Jumlah tersebut semakin meningkat secara terus menerus dari terjadinya krisis ekonomi pada tahun 1997 hingga saat ini. Hal ini bukan karena pertambahan jumlah penduduk yang tidak sebanding dengan kekayaan alam yang dimiliki, akan tetapi disebabkan oleh persoalan pendistribusian yang tidak efesien serta minimya rasa kesetiakawanan diantara sesama anggota masyarakat atau antara satu dengan yang lainnya. Salah satu lembaga yang sangat berkaitan erat dengan sosial ekonomi masyarakat yaitu lembaga wakaf. Dalam Islam menawarkan beberapa Lembaga-lembaga ekonomi yang merupakan alternatif lain apabila 
dikelola secara baik dapat mengatasi segala problematika yang ada di masyarakat. wakaf sebagai salah satu pilihan kelembgaan yang memiliki pranata keagamaan yang berciri khas ekonomis. Oleh karena itu, wakaf baiknya dikelola dan dikembangkan secara optimal agar mampu menjadi indikator dan dapat memberikan jawaban yang riil terhadap problematika yang ada dimasyarakat, terutama dalam hal ekonomi.

Namun, sangat disayangkan mengenai pemahaman masyarakat tentang wakaf yang hanya berkutat dibidang ibadah saja. Mereka cenderung berpikiran bahwa wakaf hanya diperuntukkan untuk kegiatan-kegiatan ibadah seperti masjid. Seharusnya selain hal itu, wakaf juga bisa mengarah pada pemberdayaan ekonomi umat. Pengetahuan masyarakat terhadap wakaf perlu dikembangakan terutama dalam hal harta yang akan diwakafkan, peruntukan harta wakaf, maupun perihal nadzir wakaf sebagai pengelola harta wakaf tersebut. Masalah kenadziran merupakan bahasan hukum wakaf yang paling penting karena berkaitan langsung dengan persoalan perwakafan yang meliputi pemeliharaan, memproduktifkan wakaf tersebut, dan pendistribusian hasil dari pengolahan harta wakaf yang telah dilakukan untuk pihak-pihak tertentu. Hal ini merupakan poin utama pada pengelolaan dan pengembangan aset wakaf. Seorang nadzir dalam mengelola dan mengembangkan aset wakaf juga perlu memperhatikan kuantitas atau jumlah harta benda wakaf tersbut, mengani jenis-jenisnya, bagaimana pola-pola investasinya, pendistribusiannya, serta bagaimana pengawasan yang sesuai dengan kriteria lembaga wakaf yang menuntut adanya investasi untuk mendapatkan laba atau keuntungan (Asy'ari: 2016).

Wakaf adalah harta ataupun barang yang diserahkan kepada penerima wakaf baik perorangan, organisasi ataupun badan hukum yang seketika harta tersebut diserahkan maka seketika itu pula harta tersebut menjadi milik public sebagaimana telah disebutkan dalam pasal 1 Undangundang 41 Tahun 2004. Lembaga wakaf yang merupakan nadzir dalam peruntukkan dan pengembangan wakaf memiliki fungsi dan tujuan untuk pemanfaatan, pemberdayaan, dan penggunaan harta wakaf. Selain itu lembaga wakaf juga memiliki fungsi untuk melindungi tujuan wakaf sebagaimana yang telah diikrarkan oleh wakif.

Berkaitan dengan urgensi lembaga wakaf untuk pengelolaan wakaf, di Kota Sampit belum terbentuk lembaga wakaf sebagaimana yang telah disebutkan. Dengan demikian peneliti melakukan penelitian di Lembaga Amil Zakat Nurul Fikri yang notabenenya menglola zakat namun lembaga ini juga menerima wakaf serta meneglolanya. Lembaga ini dapat dikatakan melakukan diskresi kewenangan.

Adapun yang dimaksud dengan diskresi kewenangan sebagaimana disebutkan dalam kamus besar bahasa Indonesia yaitu kebebasan mengambil keputusan sendiri disetiap situasi. Thomas J. Aaron memebrikan definisi diskresi merupakan suatu kekuasaan atu kewenangan yang dilakukan berdasarkan hukum atas pertimbangan dan keyakinan serta lebih menekankan pertimbangan-pertimbangan moral daripada pertimbangan hukum. Pendapat lain dikemumakan oleh Mahfud MD beliau menyebutkan diskresi adalah kewenanangan yang sah untuk turut campur dalam kegiatan soial guna melaksanakan tugas-tugas meneyelnggarakan kepentingan umum (Ramadhita: 2013). Adapun tindakan penggunaan diskresi hukum ini berujuan untuk mengisi kekososngan hukum, memberikan kepastian hukum dan mengatasi stagnasi pemerintah dalam keadaan tertentu guna kemanfataan dan 
kepentingan umum sebagaimana tertuang dalam undang-undang Nomor 30 tahun 2014 pasal 22 poin kedua. Tidak ada pihak yang menerima wakaf dari wakif baik berupa perorangan, organisasi, maupun badan hukum. Oleh karena itu, Lembaga Amil Zakat Nurul Fikri memebrikan kontribusi secara maksimal demi melayani kepentingan masyarakat dengan menerima wakaf yang disalurkan meskipun bukan kewenangannya untuk meneglola harta benda wakaf.

Selain itu, factor sosiologis merupakan factor utama penerimaan wakaf pada lembaga ini. Masyarakat juga memiliki kepercayaan untuk menitipkan dananya pada lembaga ini. Nurul Fikri bukan satu-satunya Lembaga Zakat yang menerima wewenang sebagai Nadzir. Hal serupa juga terjadi pada LAZ Al-Hilal di Bandung. LAZ ini melakukan presentasi rencana program wakaf uang untuk pengembangan lembaga. Al-Hilal telah menerima wakaf dalam bentuk uang yang kemudian dijadikan asset berupa lahan tanah, bangunan gedung asrama, dan saat ini sedang melakukan proyek pembangunan masjid yang dibangun khusus untuk anak yatim dan santri tahfidz. Selain itu al-Hilal juga menerima wakaf dalam bentuk fisik seperti Al-Qur'an ataupun dalam bentuk uang yang kemudian dibelikan Al-Qur'an. AlQur'an tersebut didistribusikan kepada masyarakat yang mengalami bencana alam, masjidmasjid dan juga Madrasah, TPA atau santri tahfidz yang memerlukan terutama dipendalaman atau pelosok Indonesia.

Berkaitan dengan pengelolaan wakaf yang dilakukan oleh lembaga zakat Nurul fikri yakni dengan pendanaan awal open donasi baik berupa bibit ataupun uang yang telah ditentukan oleh pihak lembaga hingga terkumpul 1200 bibit pohon sengon. Hal ini telah sesuai dengan apa yang diperuntukkan dalam undang-undang Nomor 41 Tahun 2004 tepatnya pada pasal 43 ayat 1 dan 2 bahwa seorang nadzir memiliki kewajiban untuk mengelola dan mengembangkan wakaf secara produktif dan sesuai dengan prinsip syariah.

Walaupun demikian, peranan penting yang dimiliki oleh sorang nadzir dalam pelaksanaan dan prakteknya tidak selamanya akan berjalan mulus. Karena pada realitanya terapat dalam jumlah yang cukup banyak mengenai tanh-tanah wakaf yang belum terjamah maupun dikelola secara efektif dan efesien apalagi dieksekusi untuk dengan pengembangan yang baik agar turut berkontribusi dalam memberikan kebermanfaatan bagi kesejahteraan umat secara universal. Hal ini disebabkan oleh beberapa faktor, yang meliputi sumber daya atau profesionalitas dari nadzir, budaya masyarakat, pendanaan dan yang lain sebagainya.

Sebagaimana permasalahan yang terdapat pada pengelolaan wkaaf produktif di LAZ Nurul Fikri ini. Senketa tanah yang masih belum dapat diselesiakan merupakan tugas yang harus segera diselesikan oleh nadzir itu sendiri. Dalam hal ini, lembaga Nurul Fikri telah sesuai dngan apa yang telah ditetapkan dalam Undang-undang No. 41 Tahun 2004 Pasal 62 bahwa dalam menyelesaikan sengketa tanah wakaf dapat diselesaikan melalui musyawarah. Namun hal tersebut juga belum berhasil, dan Lembaga Nurul Fikri juga belum menindak lanjuti hingga ke tingkat kepengadilan karena masih menunggu hasil dari BPN yang belum diproses. Karena inilah, urgensi dari badan wakaf yang harus berdiri secara independen, agar kendalakendala yang terjadi pada pengelolaan wakaf produktif mendapat perhatian yang lebih dan cepat diselesaikan. 
Dalam Peraturan Badan Wakaf Indonesia Nomor 3 Tahun 2012 disebutkan pada pasal 1 ayat 8 bahwa Badan Wakaf Indonesia merupakan lembaga independen dalam tugasnya mengembangkan perwakafan. Sudah jelas jika keberadaan BWI sangatlah penting untuk keberlangsungan pencapaian tujuan wakaf.

Sebagai badan yang independen, maka BWI memiliki tugas dan kewajiban sebagai tumpuan dalam melaksanakan tugasnya. Dalam undang-undang No. 41 Tahun 2004 khususnya tertuang pada pasal 49 Berdasarkan Pasal 49 Ayat 1 disebutkan bahwa kewenangan yang dimiliki oleh BWI yaitu: "membina nadzir dalam mengelola dan mengembangkan harta benda wakaf, mengelola serta mengembangkan harta benda wakaf berskala nasional dan internasional".

Walaupun demikian, peranan penting yang dimiliki oleh sorang nadzir dalam pelaksanaan dan prakteknya tidak selamanya akan berjalan mulus. Karena pada realitanya terapat dalam jumlah yang cukup banyak mengenai tanh-tanah wakaf yang belum terjamah maupun dikelola secara efektif dan efesien apalagi dieksekusi untuk dengan pengembangan yang baik agar turut berkontribusi dalam memberikan kebermanfaatan bagi kesejahteraan umat secara universal. Hal ini disebabkan oleh beberapa faktor, yang meliputi sumber daya atau profesionalitas dari nadzir, budaya masyarakat, pendanaan dan yang lain sebagainya.

Sebagaimana permasalahan yang terdapat pada pengelolaan wkaaf produktif di LAZ Nurul Fikri ini. Senketa tanah yang masih belum dapat diselesiakan merupakan tugas yang harus segera diselesikan oleh nadzir itu sendiri. Dalam hal ini, lembaga Nurul Fikri telah sesuai dngan apa yang telah ditetapkan dalam Undang-undang No. 41 Tahun 2004 Pasal 62 bahwa dalam menyelesaikan sengketa tanah wakaf dapat diselesaikan melalui musyawarah. Namun hal tersebut juga belum berhasil, dan Lembaga Nurul Fikri juga belum menindak lanjuti hingga ke tingkat kepengadilan karena masih menunggu hasil dari BPN yang belum diproses. Karena inilah, urgensi dari badan wakaf yang harus berdiri secara independen, agar kendalakendala yang terjadi pada pengelolaan wakaf produktif mendapat perhatian yang lebih dan cepat diselesaikan.

Dalam Peraturan Badan Wakaf Indonesia Nomor 3 Tahun 2012 disebutkan pada pasal 1 ayat 8 bahwa Badan Wakaf Indonesia merupakan lembaga independen dalam tugasnya mengembangkan perwakafan. Sudah jelas jika keberadaan BWI sangatlah penting untuk keberlangsungan pencapaian tujuan wakaf.

Sebagai badan yang independen, maka BWI memiliki tugas dan kewajiban sebagai tumpuan dalam melaksanakan tugasnya. Dalam undang-undang No. 41 Tahun 2004 khususnya tertuang pada pasal 49 Berdasarkan Pasal 49 Ayat 1 disebutkan bahwa kewenangan yang dimiliki oleh BWI yaitu : a) Membina nadzir dalam mengelola dan mengembangkan harta benda wakaf, b) Mengelola serta mengembangkan harta benda wakaf berskala nasional dan internasional, c)Menyetujui dan atau memberikan izin terhadap perubahan peruntukan dan status harta benda wakaf, d) Memiliki kewenangan untuk memberhentikan dan mengganti nadzir, e) Menyetujui terhadap penukaran harta benda wakaf, f) Menyarankan dan memebrikan pertimbangan kepada Pemerintah dalam penyusunan kebijakan dibidang perwakafan. 
Adapun yang melatarbelakangi pemilihan pohon sengon sebagai objek wakaf produktif yaitu karena banyaknya keunggulan yang terdapat pada Pohon Sengon. Kalimantan merupakan lahan yang tanahnya berupa tanah gambut, yang mana tidak semua pohon dapat tumbuh subur. Beberapa pohon yang banyak ditanam ditanah Kalimantan yaitu Sawit, Karet dan Sengon.

Dari beberapa keunggulan Pohon Sengon dibandingkan dengan Pohon yang lain yaitu: a) Pertumbuhannya Cepat. Tinggi tanaman akan bertambah 5-7 meter pertahunnya jika berada pada kondisi kesuburan tanah yang cukup. Jika dibandingkan dengan tanaman jati dalam kondisi lahan yang sama hanya 1-2 meter pertahunnya. b) Masa panen pohon singkat. Untuk investasi jangka menengah, budidaya pohon sengon dapat menjadi salah satu alternative. Tingkat kedewasaan serta pertumbuhan pohon sengon relative lebih cepat hingga menjadikan sengon memiliki masa tebang atau paneh yang singkat. Investasi sengon hanya memerlukan 4 hingga 6 tahun untuk siap panen. Bahkan apabila pemeliharaan yang lebih optimal, pada umur 5 tahun pun sengon sudah siap untuk ditebang. Dibandingkan dengan jati yang memerlukan waktu 15 tahun. c) Budidaya yang lebih mudah. Budidaya yang mudah menjadi factor utama pemilihan pohon sengon pada wakaf produktif ini. Setelah penanaman dan pemeliharaan yang efesien, yang meliputi diantaranya pemupukan yang dilakukan di dua tahun pertama, tidak ada pemeliharaan yang eksplisit lagi, setelah itu hanya perlu menunggu sengon siap tebang. Dibandingkan dengan budidaya sawit yang memerlukan pemeliharaan secara intens dan pemupukan yang cukup banyak. Dapat dikatakan bahwa budidaya sengon sama halnya dengan berinvestasi, penanaman modal diawal yang kemudian hanya menunggu hasil yang besarnya berkali-kali lipat. Sengon juga dapat ditanam diberbagai kondisi tanah. Dengan demikian sengon tetap dapat tumbuh meskipun ditanam pada tanah yang kurang subur. d) Multi manfaat.

Manfaat sengon tidak hanya diambil pada batang pohon, tetapi daun hingga akarnya memiliki manfaat. Daun sengon dapat digunakan sebagai bahan pakan ternak. Cabang dan ranting juga bisa digunakan untuk kayu bakar. Selain itu akar sengon juga banyak mengandung nitrogen yang bermanfaat untuk memperbaiki kesuburan tanah. Manfaat kayu sengon layak digunakan untuk berbagai kegunaan, seperti halnya untuk bahan bangunan dan furniture. Sebagai bahan bangunan, kayu sengon termasuk kayu yang memiliki kualitas kuat dan awet. Selain itu, kayu sengon juga dapat dibuat peti kayu karena memiliki fleksibilitas yang baik.

Praktek perwakafan yang terjadi dalam masyarakat sepenuhnya belum berjalan secara tertib dan efesien sehingga dalam beberapa kasus banyak harta wakaf yang terlantar dan tidak terpelihara secara semestinya. Berbagai masalah sering muncul dalam dunia perwakafan. Hal tersebut menjadi tantangan bagi seorang nadzir dalam pengelolaan wakaf serta menjadi tanggung jawab nadzirlah untuk mencari bagaimana penyelesaian dan solusi untuk menghadapi kendala-kendala yang muncul agar tujuan wakaf dapat terwujud sesuai dengan peruntukannya.

Dari hasil wawancara dijelaskan bahwa kendala utama adalah belum terbentuknya badan khusus independen yang menangani masalah perwakafan. Karena belum adanya sumber daya 
manusia yang proaktif dan berkeinginan untuk mengelola dan mengembangkan wakaf secara produtif, sehingga permasalahan ini tidak mendapat perhatian dan penyelesaian. Pihak dari Lembaga Nurul Fikri telah melakukan beberapa upaya dalam menyelesaikan sengketa tanah yang terjadi di tanah wakaf tersebut. Hanya saja usaha tersebut belum membuaghkan hasil.

Berbagai masalah kerap sekali muncul terkait pengelolaan wakaf, diantaranya seperti tanah wakaf yang belum ataupun tidak mau disertifikasi, tanah wakaf yang masih dalam sengketa dengan keluarganya ataupun pengelolaan yang belum proporsional. Hal tersebut menjadi tugas tersendiri bagi nadzir yang mengelolanya untuk mencari penyelesaian ataupun solusi agar pengelolaan wakaf tersebut dapat berjalan sesuai dengan peruntukannya. Adapun beberapa problematika wakaf yaitu: a) Kurangnya sosialisasi, b) Pengelolaan dan manajemen yang tidak optimal, c) Sistem pengawasan yang lemah, d) SDM yang menguasai tentang perwakafan (Muntaqo: 2015).

\section{Kesimpulan}

Pertama, Lembaga Zakat dalam mengelola wakaf melakukan diskresi kewenagan. Belum terbentuknya badan wakaf yang independen menjadi kendala bagi masyarakat untuk memenuhi kehendaknya dalam berwakaf. Selain itu, kewenangan yang diperoleh oleh lembaga zakat untuk menjadi nadzir wakaf dilatarbelakangi oleh factor sosiologis, yaitu banyaknya kehendak masyarakat untuk melakukan amal sholeh terutama dalam bidang wakaf. Kedua, dalam hal pengelolaan wakaf produktif berbasis pohon sengon yang bermula dari pendanaan, dinyatakan bahwa pendanaan awal diperoleh dari open donasi wakaf yang bisa berupa uang tunai ataupun bibit pohon sengon. Pemilihan Pohon Sengon sebagai objek wakaf produktif adalah karena mnyesuaikan dengan keadanaa anah dipulau Kalimantan, yaitu tanah Gambut, yang mana tidak semua pohon atau tanaman bisa dibudidaya ditanah jenis ini. Tidak adanya lembaga khusus yang menangani masalah perwakafan merupakan problematika utama yang dihadapi oleh nadzir dalam mengelola wakaf produktif di LAZ Nurul Fikri. Hal ini terjdai karena tidak adanya SDM yang mumpuni dalam hal perwakafan sehingga perhatian terhadap bidang wakaf tidak terfokuskan dan masyarakatpun memahami masalah perwakafan dalam hal yang sangat sempit. Walau demikian Lembaga ini melakukan upaya semaksimal mungkin untuk dapat mengelola wakaf yang telah diterimanya. Hal ini telah sesuai dengan apa yang diperuntukkan pada Undang-undang Nomor 41 Tahun 2004 Pasal 42 dan Pasal 43 poin (2).

\section{Daftar Pustaka}

Asikin, Amiruddin Zainal. 2006. Pengantar Metode Penelitian Hukum. Jakarta: Rajawali Press. Azhary. Tahir. 2005. Hukum Islam Zakat dan Wakaf. Jakarta: Papas Sinar Sinanti.

Balai Besar Pengkajian dan Pengembangan Teknologi Pertanian. 2008. Teknologi Budidaya Sawit. tp: Agro Inovasi.

Direktorat Jendral BIMAS dan Penyelenggaraan Haji. 2003. "Pedoman Pengelolaan dan Pengembangan Wakaf Produktif”. Jakarta: tp.

Djunaidi. Achmad. Thobieb Al-Asyar. 2007. Menuju Era Wakaf Produktif. Depok: Mumtaz Publishing. 
El-Madani. Tim. 2014. Tata Cara Pembagian Waris dan Pengaturan Wakaf. Yogyakarta: Medpress Digital.

Huda. Mitahul. 2015. Mengalirkan Manfaat Wakaf, Potret Perkembangan Hukum dan Tata Kelola Wakaf di Indonesi. Bekasi: Gramata Publishing.

Kamelia. Farha. 2018. "Pengembangan Wakaf Produktif Perspektif Maqashid Syariah Al-Syatibi, Skripsi. Malang: Uin Maulana Malik Ibrahim.

Peraturan Badan Wakaf Indonesia No. 1 Tahun 2007 Tentang Organisasi dan Tata Kerja Badan Wakaf Indonesia

Sari. Elsi Kartika. 2007. Pengantar Hukum Zakat dan Wakaf. Jakarta: PT. Grasindo.

Sugiyono. 2011. Metode Penelitian Kuantitatif dan Kualitatif dan R \& D. Bandung: Alfabeta.

Undang-undang No. 41 Tahun 2004 Tentang Wakaf

Undang-undang No. 30 Yahun 2014 Tentang Administrasi Pemerintahan

Yunus. Muhammad. 1973. Kamus Arab Indonesia. Jakarta: Yayasan Penyelenggara Penterjemah/Pentafsir Al-Qur'an.

Asyari. Hasan. 2016. "Pengelolaan dan pengembangan Wakaf Pproduktif di Yayasan Pondok Pesantren Miftahul Ulum Al-Yasin". Skripsi. Malang: UIN Maulana Malik Ibrahim Malang.

Ishari. Nurhafid. Nur Lailiah Sakinah. 2016. "Manajemen Wakaf Uang Tunai Dalam Upaya Pemberdayaan Ekonomi Umat di Pos Keadilan Peduli Umat KCP Lumajang”. Iqtishoduna. no. 1.

Khusaeri. 2015 “Wakaf Produktif”. Al-'Araf. No. 1.

Ramadhita, “Aplikasi Diskresi Dalam Pemberian Dispensasi Perkawinan”. Tesis. UIN Maliki Malang: 2013.

Samsudin. 2011. "Peranan Nadzir Dalam Pengelolaan dan Pengembangan Tanah Wakaf Pada Yayasan Pendidikan Islam At-Taqwa". Skripsi UIN Syarif Hidayatullah.

Muntaqo. Firman. 2015. "Problematika dan Prospek Wakaf Produktif di Indonesia". Jumal Al-Abkam, No.1. 25.

Samratul. Nafisah. (2019, Dec 13). LAZ Al-Hilal Mendapat Sertificat BWI dan Menjadi Nadzir Wakaf. https://alhilal.or.id/laz-al-hilal-mendapat-sertifikat-bwi-menjadinadzir wakaf/

Otak Jualan. (2019, May 20). Budidaya Pohon Sengon, Bisnis, dan Investasi Kayu Yang Kini Banyak Diminati. https://otakjualan.com/budidaya-sengon/

Admin BWI Tangsel. (https://bwitangsel.or.id/Home/tugas_wewenang, diakses pada 1 September 2020. 